\section{Las virtudes del ocio}

Carlos Cousiño Director Programa Doctorado en Sociología, Pontificia Universidad Católica de Chile

La visión antagónica del ocio y el trabajo es puesta sobre la mesa. Por un lado se mira al ocio como el momento de mayor productividad intelectual: se piensa, se siente y se observa en la quietud. Por otra parte el trabajo es entendido como lo urgente y necesario, dando lugar al movimiento constante del consumismo.

El titular principal del Düsseldorfer Mitteilungsblatt del 21 de julio de 1945 decía: "El principal deber de cada uno es trabajar". Apenas un poco después, cuando el pueblo alemán recién comenzaba la penosa tarea de reconstruir un país reducido a escombros tras el término de la Segunda Guerra Mundial, Joseph Pieper publicaba un pequeño texto destacando las virtudes del ocio. Hasta el día de hoy no se ha escrito nada comparable, tanto por la concentración de ideas en torno a un tema como por la desfachatez del momento en que se publica. Alabar el ocio en medio de la urgencia del trabajo de reconstrucción podía resultar una provocación de mal gusto, al menos que realmente fuese necesario cultivar la quietud.Y para Pieper lo era, al punto que sentía necesario hacer una apología del ocio.

Su principal argumento podría reducirse a la simple proposición que la compulsión frenética a trabajar no hace sino esconder la flojera intelectual, moral y emocional; más aún que esconde, bajo el pretexto de lo urgente e importante, la necesidad de mirarse y conocerse a sí mismo. ¿Qué duda puede caber que Pieper tenía una buena razón para llamar a ese pueblo derrotado, que había devastado el centro de Europa y llevado a la ignominia la tradición cultural de Occidente, a quedarse quieto y mirarse a sí mismo? Sin embargo debemos también reconocer que ese pueblo tenía una incuestionable necesidad de trabajar sin parar. Y es que el vínculo entre necesidad y trabajo es férreo e ineludible. Partamos por detenernos brevemente en su historia.

Lo propio de la época moderna es haber invertido la relación que se establecía en las culturas clásicas entre ocio y trabajo. Para éstas el primado era el del ocio. En Grecia, por ejemplo, el trabajo era propio del esclavo, de aquel que estaba sometido a la necesidad y no podía, por ende, ser libre ni, consecuentemente, ciudadano. Este último era un hombre que disponía de sí mismo y estaba libre de la obligación de trabajar. El espacio del trabajo era el oikos - hogar-, que es de donde proviene la palabra economía. Ese era también el espacio de la pura necesidad y de la autoridad despótica. El ocio era, por ende, condición para poder ser libre.

Para la cultura occidental premoderna el trabajo sólo se entendía como algo que permitía el ocio. El concepto de una vida contemplativa tenía una clara primacía sobre la vita activa, así como las artes liberales, propias de un hombre libre, lo tenían sobre las serviles, aquellas que debían satisfacer necesidades mediante la producción de cosas útiles. Tan sólo con la Reforma Protestante, tal como lo ha mostrado Weber, esta relación se invierte y ya no se "trabaja para vivir, sino que se vive para trabajar". Para los seguidores de Calvino el trabajo adquiere el carácter de un bálsamo a la vez que es un signo de salvación. Enfrentados a la insufrible doctrina según la cual cada persona se encuentra, desde su nacimiento, predestinada a la salvación o la condenación eterna, sin que nada de lo que haga en este mundo pueda alterar este definitivo designio divino, el trabajo sirve como vía de escape y olvido, como remedio para la enorme angustia que esta incertidumbre provoca. Al mismo tiempo el éxito en el trabajo puede ser considerado como un signo de la gracia divina. Basta tan sólo este pobre consuelo para que el hombre vuelque su vida entera al trabajo.

Incluso llevando el activismo intramundano hasta su extremo, en el giro puritano el trabajo sigue obteniendo su sentido y su importancia desde fuera del mundo de la economía humana.

Recién en nuestra época contemporánea se produce una desvinculación del

\section{The Virtues of Leisure}

Carlos Cousiño Director Programa Doctorado en Sociología, Pontificia Universidad Católica de Chile

The contrary vision of leisure and work is put on the table. On one side, leisure is seen as the most productive moment of intellectual productivity: one feels, thinks and observes in the stillness. On the other hand, work is understood as the urgent and necessary, giving place to the constant movement of consumerism.

The headline of the Düsseldorfer Mitteilungsblatt from July 21, 1945 stated: "the principal duty of each person is to work". Shortly after, when the German people had just begun the painful work of rebuilding their country reduced to rubble after the end of the Second World War, Joseph Pieper published a short text highlighting the virtues of leisure. No one has written anything comparable since, not only in terms of a the concentration of ideas on a theme but in the audacity of the moment in which it was published. To praise leisure in the midst of the urgency of the work of reconstruction could be provocation of bad taste unless it was truly necessary to cultivate stillness. And for Pieper it was, to the point of feeling the need to make a defense of leisure.

His main argument can be reduced to the simple proposition that the frenetic compulsion to work hides intellectual, moral and emotional lethargy; worse still it hides, under the pretext of emergency and importance, the necessity to examine and know oneself. Is there any doubt that Pieper had good reason to call out to this destroyed people that had devastated Europe and shamed the cultural tradition of the western world to sit quietly and examine themselves? However, we must also recognize that this people had an indisputable need to work without ceasing. An it is this relationship between necessity and work that is ferrous and unavoidable. We begin by pausing briefly in their history.

A key trait of the modern age is to have inverted the relationship between work and leisure that was established in the classic cultures. For these, the prevailing one was leisure. In Greece, for example, work was the task of slaves, subjugated to necessity and thus unable to be free nor, consequently, a citizen. The latter was a man that was at his own disposal and was freed from the obligation of work. The space for work was the oikos -home-, from which originated the word economy. It was also a space of pure necessity and despotic authority. Leisure was, therefore, the condition of the free.

For pre-modern western culture work was understood only as that which allowed for leisure. The concept of a contemplative life had clear primacy over the vita activa, just as the liberal arts of the free man stood over the servil, those that must satisfy needs through the production of useful things. With the Protestant Revolution and as Weber has showed us, this relationship has been inverted so that we know longer "work to live, but live to work". For the followers of Calvin, work simultaneously acquires the nature of a conditioner as well as is a sign of salvation. Faced with the insufferable doctrine in which each person is found, from birth, predestined for salvation or eternally condemned in which nothing done in life can alter this definitive divine designation, work serves as path to escape and forgetting, as a remedy for the enormous anguish that this uncertainty provokes. At the same time, work success can be considered as a sign of divine grace. This pitiful consolation is enough for man to turn his life over completely to his work.

Even taking this popular activism to its extreme, the puritanical turn continues to find meaning and importance outside of the realm of the human economy. 
trabajo tanto respecto de la necesidad como de cualquier sentido que provenga desde fuera de la actividad económica. Lo primero resulta del desplazamiento del concepto de necesidad desde el plano de la objetividad al de la subjetividad: la necesidad es conceptualizada ahora como demanda. Sobra decir que esta reinterpretación sólo se puede hacer en el contexto de la afluencia económica que caracteriza a las sociedades occidentales. Por otra parte, el trabajo queda legitimado desde la pura actividad económica y su único sentido queda puesto en el consumo. $\mathrm{Al}$ asociarse con el consumo, el trabajo adquiere una compulsión inevitable. Más aun, esa asociación le pone una lápida a toda posibilidad de valorar el ocio.

Pero el precio que pagamos por ello es muy caro. El ocio y la quietud, al apartarnos de la actividad mundanal, nos permiten acceder a experiencias que de otra manera nos están clausuradas o, mejor dicho, que sólo son posibles desde la no-actividad. Una de ellas, probablemente la más importante y general, es la experiencia de la gratuidad. El trabajo nos lleva a pensar en términos de esfuerzo y de logro y a entendernos a nosotros mismos como producto de nuestro trabajo. Los norteamericanos lo expresan magníficamente con la fórmula del self made man. Lo que somos y tenemos es el resultado de nuestro esfuerzo, de nuestro trabajo. La experiencia de la gratuidad supone poder escapar de ese activismo egocéntrico. Sólo desde el ocio es posible abrirse a la exuberancia del ser y a su donación originaria. Desde el trabajo sólo se percibe la escasez que requiere ser superada por el infatigable trabajo del hombre.

Referido a ello está también la clausura frente a todas aquellas experiencias que escapan a la dimensión de lo útil. Y es que desde la lógica del trabajo y del consumo las cosas aparecen ante nada como útiles o inútiles. Pero con ello quedan cerrados ámbitos muy significativos de la experiencia humana. Estos incluyen a la experiencia estética, al amor y a lo sagrado. Ninguna de estas experiencias es posible desde la perspectiva de la utilidad. Todas ellas presuponen una actitud opuesta a la actividad. En todas ellas hay que estar en condición de recibir, es decir, quieto y abierto a lo que viene hacia mí. La mejor manera de no ver, oír o apreciar lo que viene a nuestro encuentro, es estar demasiado ocupados.

De hecho estas experiencias que escapan al paradigma de la utilidad han debido protegerse, con mayor o menor éxito, de los intentos por parte del mundo del trabajo-consumo por apropiarse de ellas y colonizarlas. En su intento por huir de la instrumentalización económica el arte prefirió refugiarse en lenguajes nuevos y difíciles. La música se hizo dodecafónica o serial para escapar del jingle publicitario; la plástica se hizo abstracta, lejana a la fotografía comercial; la literatura se fue a usos cada vez más sofisticados del lenguaje y la narración para huir del ramplón eslogan de venta.

Por su parte, el amor ha estado sometido desde siempre a esta tensión, la cual proviene inevitablemente del carácter sexual del amor humano. El amor como experiencia radical está siempre amenazado por el riesgo de la rutinización. El enamorado ansía la perpetuación de ese momento que comparte con su amada; sabe que el día rompe lo que la noche ha fundido; sufre frente a la posibilidad que el amor adquiera una cotidianeidad que lo mate. El erotismo teme ser reducido a sexualidad reproductiva, ser reducido a la dimensión de la utilidad y de la necesidad, en este caso reproducir la familia, la estirpe o la especie. Los griegos consideraban que la mujer no era libre precisamente porque su condición biológica la sometía a la necesidad de la reproducción. Es por eso que el eros tiende al thanatos. Sólo la muerte de los amantes puede redimir al amor de los riesgos de la institucionalización. La gran tragedia amorosa del romanticismo, Tristán e Isolda, expresa de manera sublime esta tensión.

Ni que hablar de lo sagrado. Abrirse a esa posibilidad pasa por negar la afirmación básica del materialismo, inventor del hombre-trabajador, según la cual Dios es creado por el hombre, ya que es un concepto útil para resolver múltiples problemas sociales o individuales. El trabajo nos ancla a este mundo y desde allí no es posible acceder a la experiencia de lo sagrado, la que está siempre referida a lo que trasciende lo terrenal. El concepto mismo de religión expresa la aspiración por religar estos ámbitos que el hombre ha escindido. Pero no es la actividad del hombre la que puede hacerlo, sino precisamente la no actividad, el mantenerse atento y abierto a un Dios que viene a nuestro encuentro. La única manera de estar dispuesto a ese encuentro es permaneciendo quieto.

El costo de sacrificar el ocio al frenesí de un activismo que no puede realizarse más allá del consumo es demasiado alto. “iQuédate quieto!". Este llamado es cada vez más necesario, además de ser un imperativo si se pretende comprender, apreciar o disfrutar de las experiencias más enaltecedoras de lo humano. ARQ
Recently in our contemporary age a disconnect has appeared between work with respect to its necessity and its significance it produces apart from economic activity. Firstly, this results from the displacement of the concept of need from the objective plane to the subjective: the need is conceptualized now as a requirement. Its worth it to say that this reinterpretation can only be made in the context of the economic affluence characterizing western societies. On the other hand, work is is legitimized by pure economic activity and its only meaning lies in consumption. Through its association with consumption, work obtains an inevitable compulsion. More still, this association sends all possibility of valuing leisure to the grave.

The price we pay for this is an expensive one. Leisure and stillness, by removing us from mundane activity, allows us to access experience that would otherwise be closed to us, or better said, are only possible through this non-activity. One of these, probably the most broad and important, is the experience of the gratuitous. Work makes us think in terms of effort and achievement and to understand ourselves as products of our work. North Americans express this magnificently with the formula of the self made man. What we are and what we have are the results of our effort, of our work. The experience of gratuity supposes the ability to escape from this egocentric activism. Only through leisure is one able to open themselves to the exuberance of being and his original nature. Through work one can only perceive the scarcity that must be overcome by the indefatigable work of man.

This is paired with the closure to all these experiences that escaped the "useful" dimension. And it is from this logic of work and consumption things appear either useful or useless. But this closes off certain significant realms of human experience. In all these one must be in the condition of the receiver, that is, still and open to what comes. The best way to neither see, nor hear nor appreciate what comes to us is to be too busy.

In fact, these experiences that escape the utility paradigm have needed protection, successfully or unsuccessfully, from the attempts of the work-consume world to be appropriated and colonized. In the attempt to flee the economic instrumentalization, art has preferred to take refuge in new and difficult languages

Music became serial or dodecafonic to escape from the publicity jingle; the plastic became abstract, far from commercial photography, literature turned to more and more sophisticated uses of language and narration fled from the sales slogan.

Love, for its part, has always been subjugated to this tension that inevitable comes from the sexual character of human love. Love as a radical experience is always threatened by the risk of routinising. The lover craves the perpetuation of this moment shared with his beloved; he knows that the day breaks what the night founded; it suffers from the possibility that love acquires an everyday-ness that kills it. Eroticism fears being reduced to a reproductive sexuality, to a dimension of utility and necessity. It is for this reason that eros leans toward thanatos. Only the death of lovers can be redeemed from the dangers of institutionalization. The great love tragedy of romanticism, Tristan and Isolde, sublimely expresses this tension. Only the lover's death could redeem their loves from the risks of institutionalization. The great tragic love story of romanticism, Tristan and Isolde, sublimely expresses this tension.

And this is without even mentioning the sacred. To open up to this possibility passes from denying the basic afirmation of materialism, inventor of the man-worker, according to which God is created by man being that it is a useful concept for resolving many social and individual problems. Work anchors us to this world and from there it is impossible to access the sacred experience that is almost always referred to as transcending earthly things. The same concept of religion expresses the aspiration to reunite these realms that man has divided. But it is not the activity of man that can do this, but the non-activity, maintaining oneself attentive and open to a God that comes to meet us The only way to be available for this meeting is to be still.

The cost of sacrificing leisure to the frenzy of activism that cannot be manifested outside of consumption is too high. "iBe still!". This call is more important every day and is an imperative to understand, appreciate or enjoy the most uplifting experiences of man. ARQ 